\section{Original Article}

Dr. Md. Shahed Rafi Pavel BDS, MPH

Assistant Professor Department of Dental Public Health City Dental College \& Hospital, Dhaka.

Dr. A.K.M.Tanzir Hasan BDS, MPH

Assistant Professor

Department of Dental Public Health University Dental College \& Hospital, Dhaka.

Dr. Md. Sajedul Asif Farzan BDS, MPH Assistant Professor Department of Children, Preventive \& Community Dentistry

Pioneer Dental Coleege \& Hospital, Dhaka.

Dr. Ashis Kumar Biswas BDS, MCPS, FCPS Orthodontics and Dentofacial Orthopedics

Nasrin Akhter

M. Pharm (DU), Research fellow, Toxicology (Japan) Lecturer Department of Pharmacy North South University, Dhaka

Dr. Md. Anower Hussain Mian BDS, DDS, PhD (Japan) Post doc. fellow (USA) Associate Professor \& Head General and Dental Pharmacology City Dental College and Hospital, Dhaka-1219

\title{
Educational Intervention on HIVIAIDS among Selective Rural Women: Perspective Bangladesh
}

\section{Abstract :}

A quasi-experimental study was carried out to assess the knowledge on HIV/ AIDS among women in Boro Chondrail \& Barigaon village of Savar district from 19th April to 25th April 2009. A total of 77 women were selected purposively. Baseline data were collected through pretested structured questionnaires by face to face interview. Educational intervention was given and data were collected again using the same questionnaires. Only $49.35 \%$ heard the name of HIV /AIDS before the program. Among the respondents $18.42 \%$ heard the name of AIDS from television, 5.26\% were from radio, $2.64 \%$ were from news paper, $5.26 \%$ were from sign board and $68.42 \%$ were health workers. About the mode of transmission $29.87 \%$ said that HIV transmits by sharing syringe \& needle, $31.17 \%$ answered unsafe physical relation, $16.88 \%$ said by blood of infected person, $5.19 \%$ knew about vertical transmission and $5.19 \%$ said by breast milk before intervention. After intervention $100 \%$ said that HIV transmits by sharing syringe $\&$ needle, $100 \%$ answered unsafe physical relation, $100 \%$ told by blood of infected person, $77.92 \%$ reported vertically transmission and $88.31 \%$ said through breast milk. Majority $(70.13 \%)$ didn't know about the symptoms of AIDS before intervention. Only $11.69 \%$ identified weight loss as symptom of AIDS, $7.79 \%$ answered fever \& cough, $28.69 \%$ told weakness, $1.30 \%$ mentioned diarrhoea. After intervention which were improved to $35.06 \%$, $32.46 \%, 32.46 \%, 35.06 \%, 19.48 \%, 19.48 \%$ respectively. Before intervention $23.38 \%$ believed living in same house with an AIDS patient could infect others, $31.17 \%$ believed use same drinking glass and $14.29 \%$ believed eating together could infect others. After intervention no one found who believed in myth about AIDS. Among the respondents only $46.75 \%$ knew the role of condom in prevention of AIDS before intervention and it became $100 \%$ after the intervention. Only $12.58 \%$ knew intravenous drug users are the risk group with increased to $93.5 \%$ after the intervention. It may be concluded that the knowledge of rural women on HIV/AIDS were not good which raised significantly after the educational intervention.

Key words : HIV, AIDS.

\section{Introduction :}

Acquired Immune Deficiency Syndrome (AIDS) has become the most devastating diseases of human kind has ever faced. AIDS has been defined as a diseases cause by a retrovirus known as the Human Immune Deficiency Virus (HIV) which at- tacks and impairs the body's natural defenses system against diseases \& infection [1].Statistics for the end of 2010 indicate that around 34 million people are living with HIV, the virus that causes AIDS. Each year around 2.7 million people become infected with HIV and 1.8 million die of AIDS. 
Although HIV and AIDS are found in all parts of the world, some areas are more affected than others. The worst affected region is sub-Saharan Africa, where in a few countries more than one in five adults is infected with HIV. The epidemic is spreading most rapidly in Eastern Europe and Central Asia, where the number of people living with HIV increased by $250 \%$ between 2001 and 2010. AIDS is caused by HIV, a virus that can be passed from person to person through sexual fluids, blood and breast milk. Worldwide the majority of HIV infections are transmitted through sex between men and women, and half of all adults living with HIV are women [2] but certain groups of people have been particularly affected and these include injecting drug users, sex workers and men who have sex with men. In many people's minds, HIV and AIDS are closely linked with these groups, which can lead to even greater stigma and prejudice against people already treated as outsiders [3]. As a sexually transmitted disease, AIDS particularly affects adolescents and young adults. Three thousand new infections occur among young people aged between 15-24 every day and people in this age group account for more than a third of all new HIV infections [4]. Deaths of young adults have an especially damaging impact on their families and communities: skills are lost, workforces shrink and children are orphaned. In some African countries, life expectancies have fallen below 40 years, whereas they would have been above 60 without AIDS. There are around 16.6 million children who have lost a parent to AIDS [5].

Access to prevention tools such as HIV education, condoms, clean needles and program to prevent mother-to-child transmission is inadequate. Figures show that in 2009 , only $26 \%$ of pregnant women in low- and middle-income countries were tested for HIV and an estimated $56 \%$ of pregnant women living with HIV were given antiretroviral treatment to prevent HIV transmission to their child [6]. At the end of 2010 it was estimated that out of the 34 million adults worldwide living with HIV and AIDS, half are women [7]. The AIDS epidemic has had a unique impact on women, which has been exacerbated by their role within society and their biological vulnerability to HIV infection. Generally women are at a greater risk of heterosexual transmission of HIV. Biologically women are twice more likely to become infected with HIV through unprotected heterosexual intercourse than men. In many countries women are less likely to be able to negotiate condom use and are more likely to be subjected to non-consensual sex $[8,9]$.
UNAIDS estimates that nearly 4.8 million adults are living with HIV in Asia, approximately 34 percent of whom are women [10]. The number of women living with HIV and AIDS in Asia varies greatly between different countries, and in places largely affected by the epidemic, such as India, the numbers vary between different states. Although women are often perceived to be at low risk of HIV infection because it is not common to have more than one lifetime sexual partner, a great number of women are put at risk of HIV infection as a result of their husbands having unprotected sex outside of marriage or injecting drugs. It has been estimated that $90 \%$ of women living with HIV in Asia were infected by their husband or long-term partner [11].

Mother-to-child transmission (MTCT) is an issue that directly affects women and at the same time increases the spread of HIV. MTCT occurs when an HIV positive woman passes the virus to her baby during pregnancy, labour and delivery, or breastfeeding. UNAIDS says that at the end of 2009 there were an estimated 2.5 million children (under 15 years) living with HIV, most of whom were infected by their mothers [12].

Additionally, millions of women have been indirectly affected by the HIV and AIDS epidemic. Women's childbearing role means that they have to contend with issues such as mother-to-child transmission of HIV. The responsibility of caring for AIDS patients and orphans is also an issue that has a greater effect on women. There are a number of things that can be done in order to reduce the burden of the epidemic among women. These include promoting and protecting women's human rights, increasing education and awareness among women and encouraging the development of new preventative technologies such as post-exposure prophylaxis and microbicides. Education is one of the most effective tools in preventing HIV infections. An estimate from the Global Campaign for Education suggests that if every child received a complete primary education, around 700,000 new HIV infections in young adults could be prevented every year.[13]Increasing HIV and AIDS education can also help to reduce the stigma that people living with HIV and AIDS face. Eradicating stigma is important in the fight against HIV and AIDS because stigma can increase the vulnerability of a group that may already be at a higher risk of HIV infection. Sex workers, for example, are in many countries still both frowned on socially and criminalized. 
It is very difficult for these women to access the healthcare services they need in order to stay healthy if they risk arrest or punishment when their profession is known [14].

The ultimate aim of this study was to inform the policy makers of national HIVIAIDS prevention program about the present status of knowledge and attitude of a section of rural women.

\section{Methodology :}

It was an educational intervention study pre-test \& post-test design. In this study design the outcome was obtained by comparing pre-intervention \& post- intervention level of knowledge of rural women on various dimensions of HIV/ AIDS. The total study period was from 19th April 2009 to 25th April 2009. The study was carried out at Boro Chondrail \& Barigaon village under Dhamrai thana of Savar district. Sampling Technique: Purposive sampling technique was applied in this study. The women of Boro Chondrail and Barigaon village under Dhamrai thana of Savar district. Total sample size was 77 women of which 46 were Boro Chondrail \& 31 were Barigaon from Dhamrai thana of Savar district.

All the respondents were taken on following criteria:-

- Women on reproductive age (15-49)

- Respondent's willingness

Structured questionnaires were prepared in order to conduct interview of the respondents. Extensive literatures were reviewed before the development of tools for data collection.Pre-testing was conducted at Moshjidpara, Mohakhali. The main purpose of the pretest was taken from the feasibility of tools assess the adequacy of the measuring instruments and to detect problems related to its design. After the pre-test all necessary changes \& modifications were done as required questionnaires, items etc. Door to door interview data collection techniques were adopted for achieving objectives of the study. After collection of data, all field questionnaires were checked for completeness \& accuracy by the investigators. Data were compiled, analyzed, coded \& verified for consistency before hand in the computer master sheet.On basis of finding of the pre-test data collection, the content of educational session was planned with the aim of clarifying prevention of HIVIAIDS.Lesson plan, posters, flipchart were developed. Some other necessary materials were collected from Save the ChildrenUSA and HASAB consortium.
After baseline survey the respondents were chosen \& divided into 4 groups consisting of 20 women in 3 groups \& 17 in 1 group. All respondent were requested to be present before hand at selected place $\&$ time to participate in group education. Educational session was conducted having short presentation by using following teaching methods and materials for dissemination of knowledge.

Mini lecture : A mini lecture session was conducted on various prevention of HIVIAIDS.

Media : Flip chart and posters which content different messages for effective teaching.

Brainstorming: This session was conducted as a problem solving technique by asking question to make quick responses or suggestions to the respondents' mind. After the completion of session, feedback was taken from the respondents by asking questions.

\section{Results :}

Table - 1:- Distributions of the respondents regarding Knowledge on HIV Transmission

\begin{tabular}{|c|c|c|c|c|}
\hline \multirow{2}{*}{$\begin{array}{c}\text { Mode of HIV } \\
\text { Transmission }\end{array}$} & \multicolumn{2}{|c|}{ Pre-Intervention } & \multicolumn{2}{c|}{ Post Intervention } \\
\cline { 2 - 5 } & Frequency & Percentage & Frequency & Percentage \\
\hline $\begin{array}{c}\text { Sharing same syringe } \\
\text { \& needle }\end{array}$ & 23 & 29.87 & 77 & 100 \\
\hline $\begin{array}{c}\text { Unsafe physical } \\
\text { relation }\end{array}$ & 24 & 31.17 & 77 & 100 \\
\hline $\begin{array}{c}\text { By blood of infected } \\
\text { person }\end{array}$ & 13 & 16.88 & 77 & 100 \\
\hline $\begin{array}{c}\text { Transplanted } \\
\text { transmission after } \\
\text { delivery }\end{array}$ & 4 & 5.19 & 60 & 77.92 \\
\hline $\begin{array}{c}\text { Transmission } \\
\text { by breast } \\
\text { milk }\end{array}$ & 4 & 5.19 & 68 & 88.31 \\
\hline Don't Know & 23 & 29.87 & 00 & 00 \\
\hline
\end{tabular}

Table 2:-Distributions of the respondents by Knowledge of the symptom of AIDS

\begin{tabular}{|c|c|c|c|c|}
\hline \multirow{2}{*}{ Symptoms } & \multicolumn{2}{|c|}{ Pre-Intervention } & \multicolumn{2}{c|}{ Post Intervention } \\
\cline { 2 - 5 } & Frequency & Percentage & Frequency & Percentage \\
\hline Weight loss & 9 & 11.69 & 27 & 35.06 \\
\hline Fever \& cough & 6 & 7.79 & 25 & 32.46 \\
\hline Pneumonia & 0 & 0 & 15 & 19.48 \\
\hline Diarrhea & 1 & 1.30 & 15 & 19.48 \\
\hline Skin diseases & 9 & 11.69 & 27 & 35.06 \\
\hline Weakness & 22 & 28.69 & 25 & 32.46 \\
\hline Don'tKnow & 54 & 70.13 & 0 & 0 \\
\hline
\end{tabular}


Table 3:-Distributions of the respondents by Knowledge on HIV/AIDS

\begin{tabular}{|c|c|c|c|c|}
\hline \multirow{2}{*}{$\begin{array}{c}\text { Knowledge of wrong } \\
\text { information }\end{array}$} & \multicolumn{2}{|c|}{ Pre-Intervention } & \multicolumn{2}{c|}{ Post Intervention } \\
\cline { 2 - 5 } & Frequency & Percentage & Frequency & Percentage \\
\hline Living in same house & 18 & 23.38 & 0 & 0 \\
\hline Eating together & 11 & 14.29 & 0 & 0 \\
\hline $\begin{array}{c}\text { Use same drinking } \\
\text { glass }\end{array}$ & 24 & 31.17 & 0 & 0 \\
\hline Bathing in same pond & 5 & 31.17 & 0 & 0 \\
\hline Sleeping in same bed & 3 & 6.49 & 0 & 0 \\
\hline $\begin{array}{c}\text { Biting by mosquito or } \\
\text { insects }\end{array}$ & 8 & 3.90 & 0 & 0 \\
\hline $\begin{array}{c}\text { By hugging or } \\
\text { handshake }\end{array}$ & 01 & 10.39 & 0 & 0 \\
\hline $\begin{array}{c}\text { By sneezing or } \\
\text { coughing }\end{array}$ & 01 & 1.30 & 0 & 0 \\
\hline Using same toilet & 10 & 12.99 & 0 & 0 \\
\hline \begin{tabular}{c} 
Don't Know \\
\hline
\end{tabular} & 48 & 62.34 & 0 & 0 \\
\hline
\end{tabular}

Table :-4 Distributions of the respondents by Knowledge on HIV/AIDS Prevention

\begin{tabular}{|c|c|c|c|c|}
\hline \multirow{2}{*}{ Categories } & \multicolumn{2}{|c|}{ Pre-Intervention } & \multicolumn{2}{c|}{ Post Intervention } \\
\cline { 2 - 5 } & Frequency & Percentage & Frequency & Percentage \\
\hline $\begin{array}{c}\text { Use condom during } \\
\text { intercourse }\end{array}$ & 36 & 46.75 & 77 & 100 \\
\hline $\begin{array}{c}\text { Using disposable } \\
\text { syyinge }\end{array}$ & 11 & 14.29 & 77 & 100 \\
\hline Taking fresh Blood & 6 & 7.79 & 77 & 100 \\
\hline Safe Sex & 10 & 12.99 & 70 & 90.90 \\
\hline \& social customs & 8 & 10.39 & 62 & 84.41 \\
\hline Don't Knnow & 32 & 41.56 & 0 & 0 \\
\hline
\end{tabular}

Tabbe 5: Distributions of the respondents by knowledge on Risk group of HIV/AIDS

\begin{tabular}{|c|c|c|c|c|}
\hline \multirow{2}{*}{$\begin{array}{c}\text { Risk group of } \\
\text { HIV/AIDS }\end{array}$} & \multicolumn{2}{|c|}{ Pre-Intervention } & \multicolumn{2}{c|}{ Post Intervention } \\
\cline { 2 - 5 } & Frequency & Percentage & Frequency & Percentage \\
\hline $\begin{array}{c}\text { Commercial sex } \\
\text { wookers }\end{array}$ & 46 & 59.74 & 72 & 93.50 \\
\hline Homosex & 0 & 0 & 27 & 35.06 \\
\hline Polygamy & 12 & 15.58 & 70 & 90.90 \\
\hline $\begin{array}{c}\text { Intravenous drug } \\
\text { users }\end{array}$ & 10 & 12.58 & 72 & 93.50 \\
\hline SYI/TB & 0 & 0 & 70 & 90.90 \\
\hline Don'tKnow & 15 & 19.48 & 0 & 0 \\
\hline
\end{tabular}

Table 6: Distribution of the respondents regarding Knowledge on behave with HIV/AIDS Patients

\begin{tabular}{|c|c|c|c|c|}
\hline \multirow{2}{*}{ Responsibilities } & \multicolumn{2}{|c|}{ Pre-Intervention } & \multicolumn{2}{c|}{ Post Intervention } \\
\cline { 2 - 5 } & Frequency & Percentage & Frequency & Percentage \\
\hline $\begin{array}{c}\text { Sympathy for AIDS } \\
\text { patients }\end{array}$ & 8 & 29.87 & 77 & 100 \\
\hline $\begin{array}{c}\text { Good behaviout to } \\
\text { ADS patients }\end{array}$ & 64 & 66.23 & 77 & 100 \\
\hline $\begin{array}{c}\text { Inform to other } \\
\text { family members } \\
\text { about AIDS }\end{array}$ & 7 & 16.88 & 77 & 100 \\
\hline Others & 1 & 5.19 & 0 & 0 \\
\hline Don't Know & 7 & 29.87 & 0 & 0 \\
\hline
\end{tabular}

\section{Discussion:}

The study was conducted with the aim to assess the knowledge on HIVIAIDS among women in a selected area to find out the effectiveness of an intervention program comparing the result from the data of before intervention and after intervention program. This discussion was made on the light of findings. In this study showed Table-1 that out of 77 respondents $29.87 \%$ said that HIV transmitted by sharing syringe \& niddle. After intervention we found $100 \%$ said that HIV transmitted by sharing syringe \& niddle. Table-2 showed majority $70.13 \%$ didn't know symptom's of AIDS before intervention.Before intervention $23.38 \%$ believed that living with an AIDS patient could able to infected.After intervention no one found who said living with an AIDS patient could able to infected.

\section{Conclusion:}

From all the findings it was concluded that the knowledge of selected women on HIVIAIDS were not good before intervention. It was evident that before intervention the knowledge on HIVIAIDS of respondents raised significantly after educational intervention. This study helps us to evaluate the effectiveness of health education intervention programme. It was found that in order to improve the knowledge and attitude on healthy life style, an intervention programme is the best to achieve the gole. This study revealed that effective educational programme about matter by the health educator and health workers in collaboration with the NGO and development organization, which influence village women knowledge regarding HIVIAIDS. 


\section{References:}

1. www.who.int/gender/hiv/aids/en

2. UNAIDS (2011, November) 'World AIDS Day Report 2011

3. Centers for Disease Control and Prevention. HIVIAIDS Surveillance Report 2005, (Vol.17)

4. 'United Nations (2011) 'Personal Declaration on HIVIAIDS: Intensifying our Efforts to Eliminate HIVIAIDS

5. UNAIDS (2010) 'UNAIDS report on the global AIDS epidemic

6. WHO/UNAIDS/UNICEF (2010) 'Towards universal access: Scaling up priority HIVIAIDS interventions in the health sector'

7. UNAIDS (2011, November) 'World AIDS Day Report 2011

8. UNAIDS (2009, May), 'A strategic approach: HIV \& AIDS and education.

9. UNAIDS 'Women and girls'

10. UNAIDS (2010) 'UNAIDS report on the global AIDS epidemic

11. UNAIDS (2009), 'HIV transmission in intimate partner relationships in Asia

12. UNAIDS (2010) 'UNAIDS report on the global AIDS epidemic

13. International Planned Parenthood Foundation (2009), 'The truth about men, boys and sex: gender transformative policies and program

14. The Global Coalition on Women and AIDS (UNAIDS) (2005) 'Educate girls, fight AIDS' 